\title{
Case 2552
}

\section{Anniella pulchra Gray, 1852 (Reptilia, Squamata): proposed designation of a neotype}

\author{
Robert W. Murphy \\ Department of Ichthyology and Herpetology, Royal Ontario Museum, \\ 100 Queens Park, Toronto, Ontario, Canada M5S 2C6
}

\section{Hobart M. Smith}

Department of EPO Biology, University of Colorado, Boulder, Colorado 80309, U.S.A.

\begin{abstract}
The purpose of this application is to conserve the specific name of Anniella pulchra Gray, 1852 in accordance with its accustomed understanding and usage by the designation of a neotype. A. pulchra is the type species of Anniella Gray, 1852, a genus of fossorial, legless lizards from California and Baja California (Norte), Mexico.
\end{abstract}

1. In 1852 Gray described Anniella pulchra, a new genus and species of fossorial, legless lizard collected from California during the global voyage of H.M.S. Herald, 1845-1851. Gray's description (p. 440) was brief and he did not provide measurements or designate a type specimen. Three weeks after this publication Sir John Richardson, curator of the biological material collected during the voyage and then housed in the Haslar Royal Naval Hospital, presented a small number of reptile specimens to the British Museum, now at the Natural History Museum, London (see Hunt, 1983, p. 80). These included a single specimen of a small, legless lizard which was registered (no. BM 1852.12.4.3; not BM 1852.4.12.3 as given in Hunt, 1983, p. 83) as A.pulchra Gray, 1852 with the locality 'California'. The specimen was re-registered (no. BM 1946 8.29.32) after the Second World War and noted as the 'type'.

2. In the introduction to his paper, Gray $(1852$, p. 437) noted that 'the following new genera [including Anniella]... will be figured in the forthcoming work of the Zoology of the Voyage', and in 1854 Richardson (pp. 154, 155, pl. 28, figs. 1-5) described in detail and figured a specimen from the voyage which he called 'Anniella pulchra Gray'. It is now recognized that the description by Gray (1852) does not match that by Richardson (1854) of 'pulchra' and indeed that two species were involved (Hunt, 1983, pp. 80-81; Murphy \& Smith, 1985, p. 68; see para. 4 below). Richardson's material has since been lost (see Hunt, 1983, p. 81). Subsequently, Boulenger (1885, pp. 299-300) described $A$. pulchra sensu Gray (1852) in greater detail and recorded the single specimen presented by Richardson to the Natural History Museum, London as the 'type'. However, Gray (1852) did not state on how many specimens he based his name; since the specimens dealt with by Gray and by Richardson (1854) were from the same collection they may be regarded as syntypes of $A$. pulchra Gray, 1852 (Recommendation 72B of the Code). Neither Gray nor Richardson realized that two taxonomic species were involved. 
3. For nearly 140 years the species of fossorial, legless lizard distributed from Bahía San Quentín, Baja California (Norte), Mexico northward to the San Francisco area of central California has been referred to as Anniella pulchra Gray, 1852. Following Cope (1864), Bocourt (1881), Baur (1894) and Van Denburgh (1897), authors adopted the name sensu Richardson (1854), and not sensu Gray (1852), not realizing that they were different (see Hunt, 1983, p. 81). Two subspecies have been recognized, Anniella pulchra pulchra, a wider ranging form, and Anniella pulchra nigra Fischer, 1885 (pp. 9, 10) with a more restricted, northerly distribution. A second more southerly species, $A$. geronimensis Shaw, 1940 (pp. 225-227, figs. 1, 2) was described from Isla San Gerónimo and adjacent coastal sand dunes of the peninsula of Baja California (Norte) near Colonia Guerrero southward to Punta Baja. Both species occur in the vicinity of the purported type locality of pulchra, the region around Bahía San Quintín.

4. Hunt (1983) reviewed the genus and concluded that the specimen given to the Natural History Museum, London by Richardson (see para. 2), the so-called 'holotype' of $A$. pulchra, was a specimen of the more southerly species, A. geronimensis Shaw, 1940. Hunt referred to this more southerly species as $A$.pulchra, listing geronimensis as a junior synonym; he adopted $A$. nigra nigra Fischer, 1885 for the northern taxon formerly called pulchra nigra, and proposed a new name, A. nigra argentea Hunt, 1983 (p. 86) for the widespread subspecies previously known as $A$. pulchra pulchra.

5. The literature concerning the genus Anniella is extremely diverse, only a small portion of it being taxonomic. Numerous local and state lists and reviews, ecological accounts, locality records, range extensions, popular and amateur works have used the name. The usage of pulchra Gray, 1852 sensu Richardson (1854), both before and after 1940 referring to the northern species of Anniella, has been extensive and includes a significant amount of morphological literature, popular field guides and state check lists. A representative list of over 100 references is held by the Commission Secretariat and includes works by Blair et al. (1968), Grassé (1970), Wermuth (1965) and Wenner \& Johnson (1980). Only Bury (1983) adopted the nomenclature of Hunt (1983). Stebbins (1985), in his revised field guide, retained the current nomenclature pending the outcome of this petition (Stebbins, 1983, personal communication).

6. Adoption of the re-arrangement of the names in Anniella proposed by Hunt (1983) would result in significant and unnecessary confusion in the nomenclature. We propose to conserve the current usage of Anniella pulchra Gray, 1852 by designating specimen no. 64656 in the Museum of Vertebrate Zoology, University of California, Berkeley, U.S.A. as the neotype. This is an adult male, collected $0.8 \mathrm{~km}$ south-east of Pinnacles National Monument, San Benito County, California on 17 March 1956 by Robert C. Stebbins. The specimen is the holotype of Hunt's (1983) subspecies Anniella nigra argentea and the latter taxon becomes a junior objective synonym of Anniella pulchra Gray, 1852. We canvassed the opinions of 15 herpetologists concerned with Anniella and reported their overwhelming support for the designation of a neotype for A. pulchra (Murphy \& Smith, 1985, p. 68).

7. The International Commission on Zoological Nomenclature is accordingly asked:

(1) to use its plenary powers to set aside all previous fixations of type specimens for the nominal species Anniella pulchra Gray, 1852, and to confirm the neotype designation in para. 6 above;

(2) to place on the Official List of Generic Names in Zoology the name Anniella Gray, 1852 (gender: feminine), type species by monotypy Anniella pulchra Gray, 1852; 
(3) to place on the Official List of Specific Names in Zoology the name pulchra Gray, 1852, as published in the binomen Anniella pulchra (specific name of the type species of Anniella Gray, 1852), and as defined by the neotype designated in para. 6 above;

(4) to place on the Official Index of Rejected and Invalid Specific Names in Zoology the name argentea Hunt, 1983, as published in the trinomen Anniella nigra argentea (a junior objective synonym of Anniella pulchra Gray, 1852).

\section{References}

Baur, G. 1894. The relationship of the lacertilian genus Anniella Gray. Proceedings of the United States National Museum, 17: 345-351.

Blair, W.F., Blair, A.P., Brodkorb, P., Cagle, F.R. \& Moore, G.A. 1968. Vertebrates of the United States. ix, 819 pp. McGraw-Hill, New York.

Bocourt, M.F. 1881. Anniella, Anniella pulchra Gray. Pp. 460-462, pl. 22G, figs. 2, 2a-d in Duméril, A.H.A., Bocourt, F. \& Mocquard, M.F. Mission scientifique au Mexique et dans l'Amérique Centrale - recherches zoologiques, part 3 (études sur les reptiles et batraciens). Imprimerie Nationale, Paris.

Boulenger, G.A. 1885. Catalogue of the lizards in the British Museum (Natural History), Ed. 2, vol. 2. 497 pp., 24 pls. British Museum (Natural History), London.

Bury, R.B. 1983. Geographic distribution: Anniella nigra argentea. Herpetological Review, 14(3): $83-84$.

Cope, E.D. 1864. On the characters of the higher groups of Reptilia Squamata - and especially of the Diploglossa. Proceedings of the Academy of Natural Sciences of Philadelphia, 16: 224-231.

Fischer, J.G. 1885. Ueber eine neue Art der Gattung Anniella Gray. Abhandlungen Naturwissenschafftlichen Vereins in Hamburg, 9(1): 9-10. (Issued in the serial in 1886 but published as a separate in 1885).

Grassé, P.-P. 1970. Traité de Zoologie, vol. 14, part 2 (Reptiles. Caractères généraux et anatomie). 680 , xxxii pp.; part 3 (Glandes endocrines-embryologie-systématiquepaléontologie). Pp. 681-1428. Masson \& Cie, Paris.

Gray, J.E. 1852. Descriptions of several new genera of reptiles, principally from the collection of H.M.S. Herald. Annals and Magazine of Natural History, (2)10(59): 437-440.

Hunt, L.E. 1983. A nomenclatural rearrangement of the genus Anniella (Sauria: Anniellidae). Copeia, 1983(1): 79-89.

Murphy, R.W. \& Smith, H.M. 1985. Conservation of the name Anniella pulchra for the California legless lizard. Herpetological Review, 16(3): 68.

Richardson, J. 1854. Vertebrals, including fossil mammals, part 2 (Recent reptiles). Pp. 143-156, pls. 25-27, pl. 28, figs. 1-5 in Forbes, E. (Ed.), The zoology of the voyage of H.M.S. Herald, under the command of Captain Henry Kellett, during the years 1845-51. 171 pp., 32 pls. Lovell Reeve, London.

Shaw, C.E. 1940. A new species of legless lizard from San Geronimo Island, Lower California, Mexico. Transactions of the San Diego Society for Natural History, 9(24): 225-228.

Stebbins, R.C. 1985. A field guide to western reptiles and amphibians, Ed. 2. 336 pp. Houghton Mifflin Co., Boston.

Van Denburgh, J. 1897. The reptiles of the Pacific coast and Great Basin. Occasional Papers of the California Academy of Sciences, 5: 1-236.

Wenner, A.M. \& Johnson, D.L. 1980. Land vertebrates on the California Channel Islands: sweepstakes or bridges? Pp. 497-530 in Power, D.M. (Ed.), The California Channel Islands: proceedings of a multidisciplinary symposium. Santa Barbara Museum of Natural History, Santa Barbara, California.

Wermuth, H. 1965. Liste der rezenten Amphibien und Reptilien. Anguidae, Anniellidae, Xenosauridae. Das Tierreich, 90: 1-41. 


\section{$2 \mathrm{BHL}$ Biodiversity Heritage Library}

Murphy, Robert W. and Smith, H M. 1991. "Anniella pulchra Gray, 1852 (Reptilia, Squamata): proposed designation of a neotype." The Bulletin of zoological nomenclature 48, 316-318. https://doi.org/10.5962/bhl.part.763.

View This Item Online: https://www.biodiversitylibrary.org/item/44489

DOI: https://doi.org/10.5962/bhl.part.763

Permalink: https://www.biodiversitylibrary.org/partpdf/763

\section{Holding Institution}

Natural History Museum Library, London

\section{Sponsored by}

Natural History Museum Library, London

\section{Copyright \& Reuse}

Copyright Status: In copyright. Digitized with the permission of the rights holder.

License: http://creativecommons.org/licenses/by-nc-sa/3.0/

Rights: https://biodiversitylibrary.org/permissions

This document was created from content at the Biodiversity Heritage Library, the world's largest open access digital library for biodiversity literature and archives. Visit BHL at https://www.biodiversitylibrary.org. 